\title{
Die ontwikkeling van die leerstelling van Goddelike genesing in die Apostoliese Geloof Sending van Suid- Afrika: Enkele kerkhistoriese perspektiewe
}

$\mathrm{M} \mathrm{Nel}$

\section{ABSTRACT}

The development of the doctrine of divine healing in the Apostolic Faith Mission of South Africa: some church historical perspectives

In this study attention is given to the development of the doctrine of divine healing in the A F $M$ of $S A$, starting with its historical roots found in the holiness and revivalistic movements of the nineteenth century. A description of the preaching of the doctrine in the $A F M$ of $S A$ through the eighty five years of its history follows. The finding of the study is that some radical elements used to be present in the healing theology of the church, that these elements caused problems in the practising of divine healing, but that the church has been purged of these elements, resulting in a new emphasis on the positive aspects of divine healing.

Die leerstelling van goddelike genesing speel 'n prominente rol in die teologie en verkondiging van die Pinksterbeweging wêreldwyd. In verskillende gestaltes kom dit by alle Pinksterkerke voor. Ook in die Apostoliese Geloof Sending van Suid-Afrika (A G S van S A) het die leerstelling ' $n$ bepalende rol in sy ontstaan en ontwikkeling gespeel. In dié artikel word gepoog om die ontwikkeling van die leerstelling in die A G S van S A te rekonstrueer, met die oog op die relevansie daarvan vir die toekomstige verkondiging en praktyk.

Die hipotese van die studie is dat radikale elemente in die vroeë verkondiging van die leerstelling beklemtoon is, in navolging van Dowie en Lake, wat weldra tot probleme in die praktyk van goddelike genesing gelei het, en wat belangstelling in die leerstelling laat taan het, totdat die leerstelling van dié radikale elemente gesuiwer is.

1 DIE ROL WAT DIE LEERSTELLING VAN GODDELIKE GENESING IN DIE BEWEGINGS WAT AANLEIDING GEGEE HET TOT DIE PINKSTERBEWEGING, GESPEEL. HET

Die A G S van S A is deel van die wêreldwye klassieke Pinksterbeweging. Om die historiese antesedente van die Pinksterbeweging te beskryf is nie ' $n$ "straightforward 
historical task"2 wat in een dimensie gedoen kan word nie. Daar is ten minste drie benaderings ${ }^{3}$. In die eerste plek kan die Pinksterbeweging in lyn gesien word met die voorkoms van charismatiese verskynsels deur alle eeue in die kerkgeskiedenis. 'n Tweede weg is om die Pinksterbeweging as per se 'n Amerikaanse beweging te sien, wat sy wortels vind in Metodisme, revivalisme, die heiligheidsbeweging en konserwatiewe Protestantisme. Ten derde kan 'n "leerstellige" geskiedenis nagetrek word. Clark, Lederle et al $^{4}$ kom egter tot die gevolgtrekking dat, gesien vanuit die gesigspunt van kontinuiteit, die Pinksterbeweging met redelike sekerheid slegs enersyds verbind kan word aan die heiligheidsbeweging wat in Suid-Afrika die infrastruktuur en aanvanklike lede verskaf het vir die aanvang van die Pinksterbeweging, en andersyds aan revivalisme.

Dieselfde geld van die leerstelling van goddelike genesing: die beperking geld dat die geskiedenis slegs beskryf word vanaf die negentiende eeuse oplewing van die leerstelling in die heiligheidsbeweging en die gepaardgaande beweging van geloofsgenesing.

Die belang van die heiligheidsbeweging vir die bediening van geloofsgenesing lê daarin dat dit klem laat val op die konsep van 'n bonatuurlike ingrype van God as 'n prerogatief vir die perfeksionistiese ondervinding, en dat dit die werking van die Gees beklemtoon. Die voorveronderstelling van die heiligheidsbeweging is dat die gelowige aangeraak word met Pinksterkrag uit die hoogte, en dan as geheiligde gelowige krag uitoefen oor sonde en Satan, asook oor siekte. Die veronderstelling van die geloofsgenesingsbeweging is dat alle siekte uiteindelik aan sonde en Satan gekoppel moet word. So deel beide bewegings 'n fundamentele basis 5 .

Sedert die laaste helfte van die negentiende eeu ontstaan daar in Amerika die duidelik onderskeibare beweging van geloofsgenesing. Die belang van die beweging lê in die unieke konsep van saligheid of heil, wat gesondheid en genesing as integrale dele insluit. Die belangrikste voorstanders van die Amerikaanse geloofsgenesings-beweging is Ethan $O$ Allen, Charles Cullis wat as mediese dokter gebed en mediese hulp kombineer om siekes te bedien, William E Boardman, A J Gordon, Carrie Judd en A B Simpson.

In die periode van 1894 tot 1905 verwerf John Alexander Dowie en sy Christian Catholic Church in Zion regdeur die wèreld bekendheid vir sy besondere weergawe van die leerstelling van geloofsgenesing. Sy tydskrif "Leaves of healing" geniet die wydste sirkulasie van enige publikasie van die beweging. Tydens die Tweede Vryheidsoorlog (1899-1902) het beide Boer en Brit dit gelees, en harte is vir die koms van Pinkster na Suid-Afrika in 1908 voorberei6. In teenstelling met die res van die Amerikaanse beweging, word Dowie se leerstelling deur radikalisme gekenmerk: hy verbied die raadpleging van dokters of gebruik van medikasie vir gelowiges, en eis dat geloofsgenesing altyd onmiddellik plaasvind. Hy stig Zion City 
langs die Michiganmeer, en baseer die bestuur van die dorp op sy beginsels van redding, genesing en 'n heilige lewenswandel. Hy leer dat die Christen afgesonderd van die wêreld moet leef, en keur die gebruik van tabak, alkohol, die eet van varkvleis en die gebruik van medisyne (insluitend geboortebeperkingsmiddele) af.

John G Lake kom onder Dowie se bediening tot bekering, en Dowie se beweging vorm die leerskool vir Lake waar hy as sakeman en ouderling die stad se belange dien. Na sy doping in die Gees in 1907 getuig Lake dat dit sy genesingsbediening totaal verander het: "My nature became so sensitized that I could lay hands on any man or woman and tell what organ was diseased, and to what extent, and all about it"?

Mettertyd begin Dowie egter aan 'n grootheidswaan ly en stel homself voor as Elia die Restoreerder, die Eerste Apostel. Spoedig bedank verskeie leiersfigure rondom hom, en verloor sy kerk aansien in die Christelike wêreld. Dit is in die tyd dat Lake ook as ouderling bedank. In $1905 \mathrm{kry}$ Dowie beroerte, en in 1907 sterf hy as 'n eensame, verworpe man.

In die versplinterde kerk stap Charles F Parham met die boodskap van die Geestesdoop met gepaardgaande spreke in tale. Daar breek onder Parham se prediking herlewing in Zion City uit, maar gou skors Dowie se opvolger, W G Voliva, vir Parham en sy volgelinge uit die kerk. Die stad verloor duisende lidmate met dié skeuring. Talle latere leiers hoor Parham se boodskap en reageer daarop.

Een van Parham se latere studente is William Seymour. Parham word in 1906 gevra om iemand na 'n swart Nasarenerkerkie in Los Angeles te stuur. Seymour word gestuur, verwys in sy eerste preek na die Geestesdoop en spreke in tale, en word vir die tweede diens uit die kerk gesluit. Hy word genooi om huisbidure te begin by die huis van 'n vriend. Gou word die getalle so groot dat 'n ou gebou in Azusastraat gehuur word. Vir die volgende drie en 'n half jaar word hier byna permanent kerk gehou. Alhoewel glossolalie die hoofitem was, speel goddelike genesing 'n belangrike rol.

Dowie se Sionisme het ook Suid-Afrika bereik deur die werk van die Amerikaanse sendelinge Johannes Büchler en Daniel Bryant. Mense wat die gawe van genesing in die Sionistekerk ontvang het, het gou ook na die ander Geestesgawes begin soek, en dit by die Pinksterbeweging gevind.

Die wêreldwye gebedsherlewing wat in die tweede helfte van die vorige eeu in Brittanje en die Verenigde State van Amerika geheers het, het ook hier te lande neerslag gevind. $\mathrm{Na} 1860$ breek herlewing in verskillende gemeentes van die Ned Geref Kerk in die Kaap uit, en di Andrew Murray en G W A van der Lingen speel 'n leidende rol. In die tagtigerjare kom 'n jong onderwyser in Murray se dienste tot bekering. Pieter Louis le Roux bekwaam hom onder Murray se leiding as sendeling, en die twee sou hegte vriende bly tot met Murray se dood. Sundkler ${ }^{8}$ sê van dié vriendskap: "The relationship between these two men is one of the subtle 
turning-points in South African church history".

P L le Roux sluit in 1903 aan by die Sionistebeweging, en neem sy gemeente saam met hom nadat sy beklemtoning van geloofsgenesing tot spanning met die kerkraad van die Ned Geref Kerk, die moederkerk lei. In 1908 sluit Le Roux aan by die nuwe Pinksterkerk, en sy gemeente staan bekend as die Siontak van die A G S van S A. In 1913 aanvaar Le Roux 'n beroep na die moedergemeente, en sy gemeente lei tot die ontstaan van verskeie groeperings van die Swart onafhanklike kerk ${ }^{9}$.

\section{DIE ROL WAT DIE LEERSTELLING VAN GODDELIKE GENESING IN DIE ONTSTAAN VAN DIE A G S VAN S A GESPEEL HET}

Die politieke en sosiomaatskaplike klimaat in Suid-Afrika aan die begin van die twintigste eeu is gekenmerk deur armoede en werkloosheid, asook 'n diepe haat tussen Boer en Brit na die Anglo-Boereoorlog. 'n Atmosfeer van onsekerheid en ekonomiese resessie het geheers, met gerugte van 'n naderende wêreldoorlog ${ }^{10}$.

In April 1908 vertrek Lake en Thomas Hezmalhalch en hul gesinne na Suid-Afrika. Daniel Bryant is op pad terug na Amerika, en sy gemeente in Johannesburg stel hul gebou vir Lake se dienste beskikbaar. Feitlik oornag word dié Sionistegemeente die eerste Pinkstergemeente. By die eerste diens word die swart werknemer van ' $n$ welgestelde gesin genees. Dié genesing werk soos 'n vonk in ' $n$ kruitvat. Talle van die eerste lidmate sluit by die A G S van S A aan nadat hulle genesing ontvang het ${ }^{11}$. In 1911 skryf Lake dat daar binne drie jaar 2023 bevestigde gevalle van genesing onder sy bediening in Suid-Afrika voorgekom het.

Lake het ook op Wakkerstroom vir P L le Roux 'n diens gaan hou. Daar is die aand vyf en sestig siekes in die diens ingebring, en almal is sonder uitsondering genees ${ }^{12}$.

Die A G S van S A het van meet af vaste teologiese beginsels in verband met genesing gehad ${ }^{13}$. Veral Lake en Le Roux het hierin bepalende rolle gespeel, en hulle is sterk beïnvloed deur Sionisme en ds Andrew Murray.

- Die basiese uitgangspunt en eerste beginsel was dat siekte van Satan afkomstig is, en dat God niemand wil siek maak of hê nie. Siekte bring geen eer aan God nie; genesing van die siek mens doen dit wel. Die Bybel bring dikwels krankheid in verband met Satan en sy demoniese magte.

* 'n Tweede beginsel was dat dit God se wil was om genesing aan sy siek kinders te skenk. Dit is die belofte wat Hy in die Bybel maak. 
- 'n Derde beginsel was dat die klem op die mens se geloof geplaas is. Een van die grootste redes hoekom mense nie gesond word nie, is dan ook as ongeloof uitgewys.

In Februarie 1913 vertrek Lake terug na die Verenigde State van Amerika, waar hy saam met Cyrus B Fockler in Milwaukee werk. Hy keer nooit terug na Suid-Afrika nie. Alhoewel "geloofsgenesing", "gebedsgenesing" en "goddelike genesing" in die Verenigde State van Amerika as wisselterme gebruik is, met die klem op "faith healing", gebruik Lake in navolging van Dowie en Murray uitsluitlik die term "goddelike genesing". Die A G S van S A sou nooit 'n ander term aanvaar nie. Lake se keuse hou verband met sy kritiek op enige term wat die aandag op die mens en sy prestasie plaas, terwyl "goddelike genesing" daarop dui dat dit God se eksklusiewe werk is. Hy kan 'n mens gebruik in dié taak, maar Hy kan ook kies om sy werk sonder menslike bemiddeling te doen.

Lake definieer goddelike genesing as die verwydering van siekte deur die krag van God; die proses of daad waardeur Hy 'n beskadigde menslike liggaam, die tempel van die Gees, herstel deur die vreemde oortreder te verjaag. Goddelike gesondheid is om daagliks en elke uur in kontak met God te leef, sodat sy lewe deur die mens se liggaam, gees en siel vloei. Goddelike genesing is waardevol as 'n evangeliserende mag. Mense word getrek deur 'n teken, oor groot afstande. Lake het in sy dienste die demonstrasie van goddelike genesing gebruik om besoekers onder die oortuiging van die krag en werklikheid van God te bring. Die bediening van goddelike genesing moes bewys dat God teenwoordig is, en 'n mag is waarmee die moderne mens rekening moes hou ${ }^{14}$. Die regte benadering tot siekte, as die begin van die dood en resultaat van sonde, is om dit te sien as iets haatliks, wat bestraf, uitgewerp en vernietig moet word ${ }^{15}$.

Daar is drie soorte siektes: die siekte van die liggaam, die siel en die gees. Die basiese siekte is siekte van die gees, wat bestaan uit skeiding van God. Siekte gaan vanaf die gees na die siel en liggaam. Die mens wat ten volle genees word in sy gees, sal volkome genesing in sy liggaam geniet ${ }^{16}$.

Lake maak 'n duidelike onderskeid tussen die lyding of verdrukking wat die gelowige as deel van vervolging oor sy geloof lei, en siekte. Die Christen kan verwag dat hy versoek, vals beskuldig en vervolg sal word, sy besittings sal verloor of skipbreuk sal ly. Siekte val egter in 'n ander kategorie, en kom direk van Satan af. In die geval van siekte kan die gelowige onmiddellike verlossing verwag. "Never did Jesus tell a person that he must remain sick"17. Lake kom uit Dowie se skool en oordeel negatief oor die bydrae van die mediese wetenskap. "It is not my purpose to degrade medical practice. It is man's best efforts to lift himself out of the mess Adam brought upon the race by his high treason. I only wish to present God's 
better way"18. Dit is sonde van ongeloof as die mens sy liggaam aan die Here toevertrou, maar dan dokter toe hardloop as hy siek word.

Vir Lake lê die probleem met die hulp wat die mediese wetenskap bied daarin dat dit die mens se oog van God afhal juis wanneer God na die mens roep. Lake het saam met siekes bly bid, totdat genesing ingetree het. Hy moedig mense aan om weer en weer te gaan vir bediening totdat hul genesing finaal beslag neem ${ }^{19}$. Die genesing van die siel geniet altyd voorkeur bo die genesing van die liggaam. Die verwydering van die swakhede van die natuur is altyd ondergeskik aan die vergifnis van sonde 20 .

\section{DIE ONTWIKKELING VAN DIE LEERSTELLING VAN GODDELIKE GENESING IN DIE VERDERE GESKIEDENIS VAN DIE A G $S$ VAN S A}

Die geskiedenis van die A G S van S A val in twee breë tydvakke uiteen, wat saamhang met die skeuring wat die kerk beleef het toe die Pinkster Protestantse Kerk ontstaan het.

\subsection{Die periode voor die vyftigerjare}

Kort na Lake se vertrek word P L le Roux tot president verkies, en vir dertig jaar lei hy die kerk deur konsolidasie en gebalanseerde uitbreiding. In dié tyd is daar nie gepoog om 'n sistematies-teologiese uiteensetting of verduideliking te gee van genesings wat inherent deel van die kerk se aktiwiteite was nie. Beloftes in die Skrif is op kinderlik-eenvoudige wyse geglo. Artikels in dié periode handel oor genesing in terme van die versoeningsleer, die sonde van ongeloof deur van mediese hulp gebruik te mak en die probleme wat ondervind word omdat almal nie gesond word vir wie gebid word nie. Die tendens in artikels en geskrifte is om slegs te sê wat die Bybel sê. Daar word nie belang gestel om teologies met 'n onderwerp om te gaan nie. Trouens, die eerste vyftig jaar van die A G S se bestaan is gekenmerk deur ' $n$ heftige antipatie teen alle "teologie", en die kerk het hom daarop beroem dat hy slegs preek "wat die Bybel leer". As regverdiging hiervoor het die kerk gemeld dat hy as gevolg van die suiwerheid van sy prediking die doop soos in Nuwe Testamentiese tye bedien, dat talespraak in die kerk herstel is en dat tekens en wonders op die bediening van die Woord volg.

Die kerk se houding jeens die mediese wetenskap word steeds bepaal deur Lake en Dowie. Op 17 April 1924 word 'n petisie by die Algemene Ledekonferensie ingedien wat vra dat aksie geneem word teen lede wat hul skuldig maak aan die gebruik van alkohol, tabak, varkvleis en medisyne, asook lede wat dans. Die kerk stel sy standpunt oor dié sake duidelik. Die A G S van S A beskou mediese werk as 
iets wat nie van God kom nie. Redes vir die negatiewe houding teenoor mediese werk lê waarskynlik in die gebrek aan geld na die droogte en Depressie, die hoë tariewe wat dokters en hospitale vir behandeling gehef het, die relatiewe oneffektiwiteit van medisyne tot en met die dertigerjare en die Skrifbeskouing wat tot ' $n$ absolute eis gelei het dat gelowiges die Here alleen vir genesing moes vertrou, en dat God nooit middellik genees nie. In 1917 lei dit tot 'n hofsaak waar 'n egpaar van Krugersdorp aangekla word omdat hul kind dood is nadat hulle mediese hulp geweier het. Hulle word skuldig bevind en beboet. Veertien jaar later speel dieselfde gebeure af as ' $n$ egpaar van Port Elizabeth met tien pond beboet word nadat hulle skuldig bevind is dat hulle tot die dood van hul kind bygedra het deur beskikbare mediese hulp te weier. Verskeie afvaardigings word na die Regering gestuur om te pleit dat 'n gewetensklousule in die betrokke wet ingebou word wat A G S-lidmate in staat sal stel om mediese hulp te weier op geloofsgronde.

Gelowiges wat siek bly na gelowige gebed bly vir die kerk 'n verleentheid. Die sprake van siek gelowiges in die Nuwe Testament (1 Tim 4:20, 5:23; 2 Kor 12:7) word op allerlei wyses weg gerasionaliseer. So word opgemerk dat ongelowiges genees word na gebed, maar gelowiges nie. Die rede hiervoor word hoofsaaklik gesoek in die geestelike onvolwassenheid waarin talle gelowiges bly - "hul is nog in die kinderklas"21.

Die Benoni-skeuring van die Spade Reën in 1927 voer dieselfde rede aan vir die splitsing met die A G S as dat die kerk so wêreldsgesind geraak het dat God nie meer mense daar kan genees nie 22 .

Die Skrifgebruik van dié periode is gekenmerk deur die opeenstapeling van Skrifgedeeltes by elke stelling, wat die indruk skep dat erns met die Bybel gemaak is. Nêrens is daar egter 'n poging om die Skrifgegewens te verwerk en te sistematiseer om by ' $n$ teologiese refleksie uit te kom nie. Die antipatie wat teen alle "teologie" bestaan het, sou so iets byna onmoontlik gemaak het.

\section{$3.2 \quad$ Na die vyftigerjare}

Die vyftigerjare word gekenmerk deur verskeie ingrypende veranderinge wat die kerklewe en teologie van die A G S mettertyd radikaal wysig. As reaksie volg die skeuring van 'n groep ontevredenes in 1958, met die stigting van die Pinkster Protestantse Kerk. Ook die genesingsteologie van die kerk word indringend beïnvloed. Veranderinge in die vyftigerjare het te doen met die siening van die kerkregtelike essensie van die kerk, die ampsbeskouing, houding teenoor die geïnstitusionaliseerde kerk, maatskappy, sosiale lewe en die owerheid. Die ontdekking van sulfonamiede in 1936, en kort daarna penisillien lei tot suksesvolle behandeling van bakteriese infeksies. Hiermee is 'n redelike persentasie van siektes wat met virusinfeksies te doen het hok geslaan. Die "tweede geslag" lidmate ${ }^{23}$ kyk 
anders na die kerk en samelewing, en na die bydrae van die mediese wetenskap tot die mens se gesondheid.

Möller aanvaar dat daar ' $n$ verband bestaan tussen die duiwel en sonde en siekte. Dit is egter nie 'n direkte verband wat in 'n oorsaak-gevolgskema gepas kan word nie. Die verband lê daarin dat deur die sondeval die ganse mensdom onder die gebrokenheid gekom het. Siekte is deel van die gebrokenheid. In enkele gevalle mag siekte die gevolg wees van 'n direkte werking van die duiwel, of van individuele sonde. Maar in die meeste gevalle is siekte die vrug van die gebrokenheid wat alle mense deel, en wat eers ten volle op die nuwe aarde opgehef sal word. Dit beteken dat dit nie noodwendig God se wil is om elke siekte te genees nie. Die bewering dat God elke siekte wil (en moet!) gesond maak, berus op die veronderstelling dat elke siekte die persoonlike werk van Satan is. As die veronderstelling foutief is, word ruimte gelaat dat die gelowige siek mag wees, en dat God die gelowige met 'n doel mag laat siek bly. In dié insig van Möller lê 'n nuwe fundering vir siekteteologie. Möller stem saam met klassieke Pinksterteoloë dat genesing gebaseer is op die kruiswerk van Christus. Tog wil hy nie 'n direkte verband daartussen soek nie. Hy doen dit deur 'n kwalitatiewe verskil te maak tussen die onderskeie onderdele van die vrug van die sondeval. Die dood is verslaan, maar nog nie ten volle vernietig nie. Die mens se verhouding met God is herstel, maar die vervloeking oor die aarde geld nog. So bestaan daar 'n kwalitatiewe verskil tussen siekte as produk van die sondeval, en individuele sonde as produk. Christus speel met die een ten volle klaar, maar met die vervloeking oor die aarde moet gewag word tot die volmaakte openbaring van die Ryk van God.

\subsection{Die bydrae van dr Hannes Jonker}

Vir die eerste maal in die kerk se geskiedenis wy 'n teoloog hom uitsluitlik aan die genesingsteologie. Dr Hannes Jonker sluit in 1977 by die A G S aan. Sy doop het 'n direkte verband met sy genesing van reumatoïede artritis gehad. Na 'n kort gesprek met vader Francis MacNutt en 'n gebed begin genesing vir Jonker intree oor enkele weke, en uit sy ervaring en nadenke formuleer hy sy genesingsteologie. In die verlede, sê Jonker ${ }^{24}$, is die klemtoon eksklusief op pastorale sorg aan die sieke geplaas. Daar was van kerklik-pastorale "behandeling" van 'n sieke geen sprake nie. Die mens gaan met sy angs, siekte en nood na die spesialis, en nie na die pastor $n i e^{25}$. Ons dag sien 'n verandering: die unieke genesingsbediening van die kerk word beskou as die hart van die pastorale bediening. Die kerk se pastorale taak behels aktiewe genesing in die gebroke werklikheid. Die hoofelemente van die nuwe teologie lê in die volgende belangrike verskuiwing in die kerk: 
* vanaf die klem op die kruis, na die opstanding en Pinkster

* vanaf 'n individualistiese bediening, na 'n bediening deur die gemeente as die liggaam van Christus

* vanaf die klem op genesing van siekte, na genesing van die persoon.

Die Bybel sien siekte nie in terme slegs van die liggaam, van 'n siek orgaan of liggaamsfunksie wat versteur is nie. Siekte staan eerder in verband met die mens se gees, en verhoudings wat versteur is, in terme van skuld en vergifnis, van innerlike pyn en die behoefte aan liefde. Siekte is die oppervlakverskynsel van innerlike wanorde.

Siekte getuig van 'n verlies van die doel waarvoor die mens geskep is. Dit is die rede hoekom Jesus genesing en vergifnis in een asem noem, en hoekom genesings op dieselfde wyse van die koms van die koninkryk vertel as die vergifnis van sonde.

Die omvattende genesing van die persoon behels verskeie aspekte:

* die hantering van die trauma van wanverhoudings

- die bloutlegging van morbiede denkpatrone

- die hantering van onheilige emosies

* die aflê van 'n perverse wil

- die gebed vir liggaamlike simptome en siektes.

Dit beteken dat liggaamlike siekte dikwels slegs maar die oppervlakverskynsel van innerlike wanorde is, wat die gevolg van die kommunikasiekrisis is waarin talle moderne mense hul bevind. Dit is die produk van 'n samelewing wat ons verplig om agter maskers te lewe, om nêrens tot 'n betekenisvolle selfontsluiting te kan kom nie.

Slegs 2 tot $10 \%$ van mense vir wie gebid word, so beweer Jonker, ontvang genesing by die massagenesingsdiens, terwyl die meerderheid kort daarna hul genesing verloor. Die enigste oplossing vir hierdie situasie is dat die gemeente weer die kragveld van die gemeenskap van die Heilige Gees word, waarbinne genesing spontaan plaasvind. Vanuit dié veronderstelling poneer Jonker sy behandelingsmetode vir kerklike genesing, koinoterapie. Dit verwys na genesing as vrug van die gemeenskap van die Heilige Gees (die gemeente). Dit verwys verder na genesing van die siek persoon, die mens, in sy totale persoonlikheid: verhoudings, denke, gevoel, wil en liggaam. Koinonia lei tot 'n totale transformasie van lewe, waardes en doelstellings. Dit is die toepassing van die beginsels van die koninkryk op die gemeente se lewe, sowel as op individue se lewe.

Die enigste uitweg uit die gewaande onafhanklikheid lê in ons onderwerping aan die gesag van Christus en aan mekaar uit eerbied vir Christus. Dit kan 
eers sinvol gebeur wanneer ons die dinamika van die kleingroep in die gemeente herontdek. In die atmosfeer van die kleingroep leer die pasiënt om rustig in sy gees te word, om in sy liggaam te ontspan, om sy hele gemoed vir die teenwoordigheid van God oop te stel, om van vrees, verwyte, angs en skuld gereinig te word, om die beantwoording van gebede te visualiseer, om homself vry van siekte te sien as beoefening van geloof, en om die Here vir sy liefde te dank.

Die elemente waaruit sy metode van koinoterapie bestaan, is:

* individuele diepte-gesprek met die berader,

* koinonia-gesprek in die kleingroep,

- die bediening van die Geestesgawes in beide gesprekke,

- handoplegging en salwing met olie,

* gebed, vergifnis en vryspraak,

* aanbidding en verkondiging, en

- nasorg.

Jonker ${ }^{26}$ gee die volgende resep vir goeie gesondheid:

* goeie interpersoonlike verhoudings,

* empatiese vermoëns,

- openheid vir ervarings, en

- meditasie, of die vermoë om stil te word in jou gees voor die Here sodat jy in jou gees die genade kan ontvang vir siel en liggaam.

\section{DIE ROL VAN DIE LEERSTELLING VAN GODDELIKE GENESING IN DIE TOEKOMS VAN DIE A G S VAN S A}

Die hipotese van die studie is dat die beklemtoning van die leerstelling van goddelike genesing in die A G S van S A met tyd getaan het omdat verskeie elemente wat daarin verweef was, praktiese en teologiese probleme veroorsaak het. Hier word kortliks krities na dié aspekte gekyk, met die doel om bakens vir die pad vorentoe op te stel.

\subsection{Houding jeens die mediese wetenskap}

Daar is reeds verwys na die gelowige se houding jeens die mediese wetenskap, en die standpunt is gestel dat genesing God se werk is wat Hy middellik of onmiddellik kan doen. Die moderne dag sien die gevaar dat gelowiges met hul siekte in afgodery kan verval. Hiermee word bedoel dat hulle hul siekte slegs in sekularistiese terme sien en verstaan, as iets wat met die liggaam en die mediese professie te doen het ${ }^{27}$. Slegs in kritieke gevalle sal die kerk se hulp ingeroep word, 
byna om nou die "laaste oliesel", by wyse van spreke, te kom bedien. Wat nodig is, is dat die gelowige sy siekte voor die Here bring, terwyl hy die dokter raadpleeg of medikasie gebruik. Maddocks ${ }^{28}$ stel voor dat gebid word voor medisyne gebruik word, net soos gebid word voor 'n ete genuttig word.

\subsection{Dié wat nie gesond word na gebed nie}

Die tergende vraag hoekom sommige gelowiges nie na gebed gesond word nie het die kerk deur alle tye tot besinning genoop. Goddelike genesing is 'n gekompliseerde saak wat altyd 'n misterieuse element bevat, omdat dit God se werk is. Deur dit voortdurend in gedagte te hou, kan simplistiese antwoorde aan mense wat ly, vermy word, en kan gewaak word teen grootmoedigheid asof die bedienaar self belangrik in die proses van goddelike genesing is.

\subsection{Genesing in die massa-evangelisasiediens}

Lederle ${ }^{29}$ kritiseer die massa-evangelisasiediens waar genesing as lokaas gebruik word omdat dit gekenmerk word deur manipulasie van mense, oordrewe eise, vertoonkuns en simplistiese Skrifgebruik. Möller ${ }^{30}$ meen dat dié dienste gekenmerk word deur die gebruik van groepsgees en massa-suggestie, 'n verwarring tussen psigiese prosesse wat benut word en die beweging van die Heilige Gees. Gee ${ }^{31}$, met sy kenmerkende wysheid, som die probleem van die beoordeling van 'n spesifieke genesingsbediening bondig op: "What all true Pentecostal hearts desire is to distinguish between the wheat of an authentic moving of the Holy Spirit and the chaff of individualistic exploitation of a popular cult for personal ends". Die groot beswaar wat wel geopper moet word, is dat genesingsevangeliste dikwels die genesingsbediening losgemaak het van die gemeente deur dit slegs in die massadienskonteks te plaas. Deurdat genesing as evangelisasiemiddel gebruik word, word genesing eksklusief gekoppel aan individue met besondere gawes. Hierdeur raak die kerk verarm, want saam met die verskuiwing van die genesingsbediening na buite die gemeente, het die rol en funksie van die lidmaat verlore gegaan.

\section{4 'n Kerklike siening van siekte}

Die oorsake van siekte is gekompliseerd. Dit kan emosioneel, fisiologies, geestelik, chemies of demonies wees, of 'n kombinasie hiervan. 'n Korrekte diagnose deur die kerk is 'n voorwaarde vir die korrekte behandelingswyse. Wanneer saam met siekes gebid word, is die Geestesgawes se nut in 'n korrekte diagnosering van siekte van onskatbare waarde. Goddelike genesing moet in terme van ten minste vier 
behandelingsmetodes bespreek word - 'n geestelike, innerlike, fisiese en bevrydingsbediening.

Geestelike gesondheid is primêr aan alle genesing. Die behandelingsmetode is: die mens konfronteer sy sonde, bely dit, doen geskikte dade van belydenis en versoening, ontvang God se vergifnis en aanvaar dit in die geloof, en leer om elke dag ander te vergewe omdat hy elke dag God se vergifnis nodig het.

Emosionele of innerlike genesing is die genesing van die innerlike mens, die proses waar die mens deur gebed vrygestel word van gevoelens van haat, bitterheid, verwerping, selfbejammering, depressie, skuld, vrees, smart, veragting, minderwaardigheid, veroordeling of waardeloosheid. Dit is die genesing van die mens se denke, emosies, pynlike herinneringe en drome. Dit is die werk van die Heilige Gees wat vergifnis van sonde deurtrek na emosionele vernuwing van beskadigde denke, wil en emosies. Dit is die toepassing van God se genade en vergifnis in dié areas van die innerlike mens wat ons daarvan weerhou dat ons die oorvloedige lewe in Christus smaak.

Soms bestaan daar geen ander oorsaak van siekte as 'n bloot fisiologiese nie. Dan kan en mag die kerk met vrymoedigheid bid vir fisiese genesing.

Demoniese betrokkenheid is dikwels deur Jesus as oorsaak van siekte gediagnoseer. So is daar sprake van ' $n$ blinde en stom demoon, 'n doofstom demoon, 'n onrein demoon, ensovoorts. Die dwelmkultuur, alkoholisme, beheptheid met Oosterse godsdienste, spiritualisme en die okkulte kan goeie ingange vir demoniese geeste bied, wat tot siekte aanleiding mag gee. Die stappe wat gevolg moet word wanneer demonisering vermoed word, of wanneer die Heilige Gees dit as die oorsaak van die siekte aangedui het, is: die persoon moet in geloof Christus as sy Here aanneem en elke area van sy lewe aan sy heerskappy onderwerp, die geeste moet in Jesus se Naam verdryf word en die persoon moet betrokke raak by die gemeente.

Wat belangrik is, is dat die bedienaar siekte korrek moet diagnoseer sodat die korrekte kerklike behandelingsmetode gevolg kan word.

\section{5 'n Kwalifisering van "geloof"}

Die Nuwe Testament stel twee duidelike voorwaardes vir genesing: geloof en gebed. Wat is die inhoud van geloof? Geloof word wyer beskou as wat sommige geloofsgenesers dit definieer, om belydenis en ' $n$ nuwe lewenswyse in te sluit. Geloof is die raamwerk van denke waarin God naby genoeg aan die mens kan kom dat Hy sy werk doen. Dit is 'n lewenswyse wat getuig van vertroue in wat God gedoen en gese het. Geloof is gebaseer op die Woord van God wat deur die Heilige Gees aan die hart van 'n mens gebring word. Geloof doen nie die wonderwerk nie, maar skep die klimaat waarbinne die krag van God vrygestel kan word. Geloof lei tot 'n lewe van 
gehoorsaamheid. En gesondheid is 'n noodwendige produk van 'n lewe wat aan God gehoorsaam is. "Die belangrikheid dat die mense volgens die beginsels van die koninkryk van God moet leef om gesond te word en gesond te bly, moet altyd beklemtoon word. Gesondheid is 'n gawe van God, aan mense wat volgens sy wil lewe", sê Hattingh ${ }^{32}$.

\subsection{Die belang van deurwekende gebed}

Een van die gevolge van 'n genesinsgbediening wat in liefde aan siek mense volvoer word, sal wees dat die kerk volle verantwoordelikheid vir sy siekes aanvaar, totdat hulle gesond is. Dit is veral belangrik as genesing nie onmiddellik intree nie. Dikwels word gevind dat hoe langer 'n persoon siek is, hoe langer neem die genesing. MacNutt ${ }^{33}$ praat van deurwekende gebed as God se bestralingsmetode. Die siek liggaamsdeel word op 'n gereelde basis in die helende lig van God opgehou. Hoe langer dit gedoen word, hoe meer droog die vergroeisels en kwaad op en verdwyn die kieme. Wanneer gebed so beskou word, word dit moontlik om te praat van grade van vordering by siek mense.

Dit het duidelik uit die kerkhistoriese navorsing geblyk dat die leerstelling van goddelike genesing in die vroeë A G S van S A 'n prominente rol gespeel het, maar dat belangstelling daarin mettertyd verflou het. Die rede hiervoor is gesoek in die hipotese dat enkele radikale elemente in die leerstelling vir die kerk se genesingspraktyk probleme geskep het. Dié elemente is geidentifiseer as die negatiewe gesindheid jeens die mediese wetenskap, die direkte oorsaaklike verband wat tussen siekte en sonde gelê is, die Skrifbeskouing van verbale inspirasie en fundamentalisties-literalistiese uitleg, en die fokus van genesing wat van die hart van die gemeente na die massagenesingsdiens verskuif het. Dr F P Möller sou dié elemente identifiseer, terwyl dr J P L Jonker die alternatiewe daarvoor bied.

Die slotsom is dat die gestelde hipotese 'n verklaring bied vir die verskuiwing van die leerstelling van goddelike genesing vanaf die kern van die verkondiging na die periferie, terwyl dit ook die nuwe beklemtoning daarvan in die kerk verduidelik.

\section{NOTAS:}

1 Dié artikel is gebaseer op die proefskrif van M Nel wat in 1992 ingedien is, met die titel "Die leerstelling van goddelike genesing soos dit in die Apostoliese Geloof Sending van Suid-Afrika ontwikkel het: 'n kerkhistoriese perspektief" vir die D D-graad in die Departement Kerkgeskiedenis aan die 
Teologiese Fakulteit (Afdeling B) van die Universiteit van Pretoria. Die promotor was prof J W Hofmeyr.

2 M S Clark, H I Lederle et al, What is distinctive about Pentecostal theology?, Pretoria 1989, 8.

3 L D Hart, A critique of American Pentecostal theology, Southern Baptist Theological Seminary 1978, 12.

4 Clark, Lederle et al, $a w, 9$.

$5 \quad$ P G Chappell, The divine healing movement in America, Drew 1983, 73-80.

6 I S v d M Burger, Die geskiedenis van die Apostoliese Geloof Sending van SuidAfrika (1908-1958), Braamfontein 1987, 60.

7 G Lindsay (ed), The new John G Lake sermons, Dallas 1971, 17.

8 B G M Sundkler, Zulu Zion and some Swazi Zionists, London 1976, 14.

9 Hier skei die paadjie, sodat die leerstelling van goddelike genesing afsonderlik in die blanke kerk en die onafhanklike kerke ontwikkel, asof in onderskeie (aparte) wêrelde.

$10 \mathrm{~J}$ E Bosman, Teorieë vir 'n genesingsbediening in die Apostoliese Geloof Sending van Suid-Afrika, Pretoria 1988, 48.

11 Burger, $a w, 178$.

12 G Lindsay (ed), The John G Lake semons on dominion over demons, disease and death, Dallas (1949)1979, 72-3.

13 Burger, $a w, 177-8$.

14 W H Reidt, Jesus. God's way of healing \& power to promote health. (Featuring the miracle ministry of dr John G Lake), Tulsa 1981, 37.

$15 \quad$ Reidt, $a w, 1981,167$.

16 Lindsay, $a w, 1971,37$.

17 Reidt, $a w, 1981,56$.

18 Reidt, $a w, 1981$, Preface.

19 Reidt, a $w, 1981,117$.

20 G Lindsay (ed), Spiritual thunder, the God-men and other sermons by John $G$ Lake, Dallas 1976, 45.

21 E D Stuart, "Goddelike genesing vir die gemeente" in Trooster en boodskapper van hoop 2/2, Februarie 1933, 4. 
22 Burger, $a w, 248$.

23 Burger, $a w, 297$.

24 H Jonker, "New accents on the healing ministry of the church", in: P G R de Villiers (ed), Healing in the name of God, Pretoria 1986, 143.

25 J P L Jonker, "Siekte en genesing vanuit 'n geloofsperspektief", in: A J Smuts (red), Predikant en pastorale praktyk. Teologiese en sielkundige perspektiewe, Pretoria 1989, 240.

26 H Jonker, Die krag van verhoudings. Pastorale teologie 2, Braamfontein s a, 15.

27 K J Kraan, Genezing en bevrijding. Deel 2: Spanningen in de dienst der genezing, Kampen 1984, 43.

28 M Maddocks, The Christian healing ministry, London 1990, 93.

29 H I Lederle, "Models of healing: a denominational charismatic perspective", in: P G R de Villiers (ed), Healing in the name of God, Pretoria 1986, 133.

30 F P Möller, Die diskussie oor die charismata soos wat dit in die Pinksterbeweging geleer en beoefen word, Braamfontein 1975, 230.

31 D Gee, Toward Pentecostal unity, Springfield 1961, 40.

32 W J Hattingh, Verkondiging en viering as terapeutiese momente in pastorale versorging, Pretoria 1984, 290.

33 F MacNutt, The power to heal, Toronto 1977, 13-4. 